\title{
PELATIHAN PENINGKATAN PENGELOLAAN BADAN USAHA MILIK DESA (BUMDES) DESA CIBINUANG KABUPATEN KUNINGAN
}

\author{
Roni Nursyamsu dan Erik Kurniadi \\ Fakultas ILmu Komputer, Universitas Kuningan, Indonesia \\ E-mail : roninursyamsu@gmail.com
}

\begin{abstract}
Community Service (PkM) is a medium to connect higher education/university with the community in order to make community being able to face challenges. In the future, especially in the era of globalization, entrepreneurship in Kuningan Regency is one of the pilot projects that can be used as opportunities to improve community welfare through entrepreneurship opportunities. This service aims at Community Empowerment through improving the management of Village-Owned Enterprises (BUMDes) for village officials and BUMDes managers as a basis for increasing capacity both individually and government in Cibinuang Village, Kuningan District, Kuningan Regency. The method used in this activity is the lecture method, question and answer method and discussion method. The core objective of this service is community empowerment through improving the management of Village-Owned Enterprises (BUMDes), so that BUMDes managers have the ability to run programs that are suitable on target so they can be accounted for in accordance with applicable regulations, especially in Cibinuang Village, Kuningan District, Kuningan Regency. It is hoped that further program in the future, it requires follow-up by the Regional Government and all related parties and it is necessary to carry out a closer and more planned collaboration between universities and local governments to explore the potencies that exist in the region.
\end{abstract}

Keywords: BUMDes, BUMDes Management

\begin{abstract}
Abstrak
Pengabdian kepada Masyarakat $(\mathrm{PkM})$ merupakan suatu media untuk menjembatani dunia pendidikan dengan masyarakat dimana Perguruan Tinggi dihadapkan pada masalah bagaimana agar warga masyarakat mampu menghadapi tantangan. Lebih jauh ke depan di era globalisasi dengan berwirausaha di Kabupaten Kuningan menjadi salah satu pilot proyek yang dapat dijadikan peluang untuk meningkatkan kesejahteraan masyarakat melalui peluang berwirausaha. Pengabdian ini bertujuan untuk Pemberdayaan Masyarakat melalui peningkatan pengelolaan Badan Usaha Milik Desa (BUMDes) bagi aparatur desa dan Pengelola BUMDes sebagai dasar untuk meningkatkan kemampuan baik secara individu maupun secara lembaga desa di Desa Cibinuang Kecamatan Kuningan Kabupaten Kuningan. Metode yang digunakan dalam kegiatan ini yaitu metode ceramah, tanya jawab dan metode diskusi. Adapun tujuan inti dari pengabdian ini adalah pemberdayaan masyarakat melalui peningkatan pengelolaan Badan Usaha Milik Desa (BUMDes), sehingga pengelola BUMDes memilki kemampuan dalam menjalankan program yang tepat sasaran agar bisa dipertanggungjawabkan sesuai dengan aturan yang berlaku, khususnya di Desa Cibinuang Kecamatan Kuningan Kabupaten Kuningan. Harapan lebih jauh ke depan tentunya diperlukan tindak lanjut oleh Pemerintah Daerah dan semua pihak yang terkait serta perlu dilakukan kerjasama yang lebih erat dan terencana antara Perguruan Tinggi dengan Pemerintah Daerah untuk menggali potensi-potensi yang ada di wilayah tersebut.
\end{abstract}

Kata Kunci : BUMDes, Pengelolaan BUMDes 


\section{PENDAHULUAN}

Pemerintah Desa merupakan bagian pemerintah yang secara langsung bertujuan untuk meningkatkan kesejahteraan masyarakat. Ketika desa mampu secara mandiri menyediakan kebutuhan warganya, maka desa telah mampu mensejahterakan warga sekaligus mengadakan pendapatan desa itu sendiri. Desa merupakan sistem kemasyarakatan bangsa yang kokoh untuk mengembangkan sistem politik, sosial, budaya, ekonomi, dan hankam. Dalam rangka mengakomodasi potensi desa dan pemenuhan kebutuhan warga desa, melalui Undang-undang Nomor 23 tahun 2014 tentang Pemerintah Daerah, pemerintah memberikan dukungan besar agar desa memiliki badan usaha yang mampu mengembangkan dan menggerakkan perekonomian lokal.

Berdasarkan Undang-undang Nomor 23 tahun 2014 Terdapat 7 (tujuh) ciri utama yang membedakan BUMDes dengan lembaga ekonomi komersial pada umumnya yaitu:

1. Badan usaha ini dimiliki oleh desa dan dikelola secara bersama;

2. Modal usaha bersumber dari desa (51\%) dan dari masyarakat (49\%) melalui penyertaan modal (saham atau andil);

3. Operasionalisasinya menggunakan falsafah bisnis yang berakar dari budaya lokal (local wisdom);

4. Bidang usaha yang dijalankan didasarkan pada potensi dan hasil informasi pasar;

5. Keuntungan yang diperoleh ditujukan untuk meningkatkan kesejahteraan anggota

6. (penyerta modal) dan masyarakat melalui kebijakan desa (village policy);

7. Difasilitasi oleh Pemerintah, Pemprov, Pemkab, dan Pemdes;

8. Pelaksanaan operasionalisasi dikontrol secara bersama (Pemdes, BPD, anggota).

BUMDes merupakan suatu lembaga ekonomi desa dimana modal usahanya dibangun atas inisiatif masyarakat dan menganut asas mandiri. Hal ini berarti pemenuhan modal usaha BUMDes harus bersumber dari masyarakat. Meskipun demikian, tidak menutup kemungkinan BUMDes dapat mengajukan pinjaman modal kepada pihak luar, seperti dari Pemerintah Desa atau pihak lain, bahkan melalui pihak ketiga. Hal tersebut sesuai dengan Undang-undang Nomor 23 tahun 2014 tentang Pemerintahan Daerah Pasal 213 ayat 3). Penjelasan ini sangat penting untuk mempersiapkan pendirian BUMDes, karena implikasinya akan bersentuhan dengan pengaturannya dalam Peraturan Daerah (Perda) maupun Peraturan Desa (Perdes).

Untuk menunjang peningkatan ekonomi desa, perlu adanya Badan Usaha Milik Desa (BUMDes) yang dapat menjadi wadah pemerintah desa dan warganya yang secara proporsional dalam melaksanakan program pemberdayaan perekonomian di tingkat desa. Keberadaan BUMDes diharapkan mampu menrangsang dan menggerakakan roda perekonomian desa. Badan Usaha Milik Desa (BUMDes) adalah sebuah perusahaan yang dikelola oleh masyar akat desa dan kepengurusanya terpisah dari pemerintah desa. Berdirinya BUMDes bertujuan untuk menggali dan mengoptimalkan potensi wirausaha desa yang secara legal dilandasi oleh Undang-Undang Nomor 32 Tahun 2004 tentang Pemerintahan Daerah Pasal 213 ayat (1) bahwa "Desa dapat mendirikan badan usaha milik desa sesuai dengan kebutuhan dan potensi desa". BUMDes didefinisikan sebagai badan usaha yang seluruh atau sebagian besar modalnya dimiliki oleh Desa melalui penyertaan secara langsung yang berasal dari kekayaan desa yang dipisahkan guna mengelola aset, jasa pelayanan, dan usaha lain untuk sebesar-besarnya kesejahteraan masyarakat Desa. 
Berdasarkan uraian di atas, permasalahan yang dihadapi oleh lembaga mitra dalam kegiatan ini dapat dirumuskan sebagai berikut:

1. Pengelolaan BUMDes belum sesuai dengan peraturan dan perundangundangan yang ada. Hal ini disebabkan pemahaman dan keterampilan Pengelola dan aparat pemerintah desa dalam pengelolaan Usaha melalui BUMDes belum berjalan secara baik.

2. Meningkatkan pengolahan potensi desa sesuai dengan kebutuhan masyarakat sebagaimana diatur dalam UU Nomor 6 tahun 2014 tentang desa.

Mengacu pada permasalahan tersebut di atas, maka tujuan dari Kegiatan Pengabdian pada Masyarakat ini adalah sebagai berikut:

1. Memberikan penyuluhan kepada pengelola BUMDes dan Perangkat Desa dalam rangka meningkatkan kesejahteraan masyarakat di Desa Cibinuang.

2. Memberikan motivasi kepada masyarakat khususnya pengelola BUMDes dan perangkat desa di Desa Cibinuang Kecamatan Kuningan Kabupaten Kuningan sehingga memiliki pengetahuan dan keterampilan untuk berwirausaha dalam meningkatkan ekonomi masyarakat.

3. Terbinanya kerjasama yang baik antara masyarakat di Desa Cibinuang Kecamatan Kuningan Kabupaten Kuningan dengan Civitas Akademika Universitas Kuningan khususnya dalam pelaksanaan Pengabdian Kepada Masyarakat.

\section{METODE PELAKSANAAN}

Berdasarkan permasalahan yang ditemukan dan dirumuskan, maka kerangka pemecahan masalah yang dilakukan melalui kegiatan Pengabdian Pada Masyarakat ini adalah PELATIHAN PENINGKATAN PENGELOLAAN Bumdes DI DESA CIBINUANG yang berpotensi menggerakkan roda perekonomian desa dan mampu meningkatkan kesejahteraan warga masyarakat. Metode dalam kegiatan pengabdian masyarakat ini adalah partisipasi aktif dengan tahapan kegiatan sebagai berikut:

1. Ceramah, tanya jawab

2. Metode ceramah digunakan untuk menyampaikan penjelasan kepada peserta tentang materi terkait pengelolaan BUMDes.

3. Diskusi

4. Diskusi dilakukan untuk menggali persoalan-persoalan yang berhubungan dengan pengelolaan BUMDes, kewirausahaan, penciptaan, pengembangan usaha berdasarkan potensi diri dan potensi lingkungan desa.

Kerangka pemecahan masalah yang telah dirumuskan kemudian direalisasikan dalam beberapa tahapan kegiatan sebagai upaya merealisasikan pemecahan permasalahan tersebut. Adapun tahapan kegiatan yang dilakukan dalam kegiatan pengabdian kepada masyarakat ini adalah sebagai berikut:

1. Tahap Persiapan

Observasi awal dan evaluasi lapangan dilakukan pada organisasi BUMDes, dengan cara melakukan pengamatan dan analisis terhadap data potensi usaha yang dapat dikembangkan di Desa Cibinuang. Berdasarkan hasil observasi diperoleh informasi. Hasil evaluasi tersebut didiskusikan dan ditindaklanjuti dengan merancang alternative solusi, untuk perencanaan selanjutnya. 


\section{Tahap Pelaksanaan}

Berdasarkan data yang diperoleh pada saat observasi tersebut, maka tim pengabdian kepada masyarakat menyelenggarakan seminar tentang Peningkatan Pengelolaan BUMDes di Desa Cibinuang Kec. /Kab. Kuningan. Para pengelola BUMDes diundang oleh Pemerintah Desa Cibinuang untuk mengikuti rangkaian kegiatan sesuai dengan jadwal pelaksanaan kegiatan. Seminar tentang kepeloporan pemuda dalam Peningkatan Pengelolaan BUMDes di Desa Cibinuang Kec. / Kab. Kuningan diisi dengan pemaparan materi yang sesuai dengan tema. Materi-materi yang disampaikan kepada peserta meliputi: Perencanaan, Penganggaran , Pelaksanaan, Penatausahaan, Pelaporan dan Pertanggung jawaban BUMDes. Lokasi yang digunakan untuk kegiatan pelatihan adalah di balai desa Desa Cibinuang Kec. / Kab. Kuningan. Pelatihan Peningkatan Pengelolaan BUMDes dibagi menjadi tiga kegiatan, yaitu ceramah dan tanya jawab tentang pengelolaan BUMDes. Pada akhir sesi diadakan tanya jawab dan sharing dengan peserta mengenai kesulitan-kesulitan dan pengalaman yang pernah dialami peserta dalam hal pengelolaan BUMDes, kewirausahaan, penciptaan, pengembangan usaha berdasarkan potensi diri dan potensi lingkungan desa. Permasalahan-permasalahan tersebut dikaji dan dibimbing oleh tim pengabdi untuk dicari solusinya.

\section{HASIL DAN PEMBAHASAN}

Pelaksanaan kegiatan Pengabdian pada Masyarakat secara keseluruhan berjalan dengan lancar sesuai dengan rencana yang telah dibuat. Jumlah peserta yang hadir dalam kegiatan ini adalah unsur pemerintah/perangkat, BPD, LPM, Pengelola BUMDes dan para pelaku usaha di Desa Cibinuang berjumlah 40 orang. Pelaksanaan pengabdian kepada masyarakat melalui kegiatan pelatihan dalam pengelolaan badan usaha milik desa bertujuan untuk meningkatkan kemampuan pengelola BUMDes dan Aprat desa dalam memanfaatkan dana BUMDes dengan sebaik mungkin, agar tidak terjadi kesalahan dalam pengunaan dana masyarakat tersebut. Sebagaimana telah dinyatakan sebelumnya, Pemberdayaan Masyarakat melalui peningkatan Pengelolaan Badan Usaha Milik Desa (BUMDes) meliputi: perencanaan, pelaksanaan, penatausahaan, pelaporan, dan pertanggungjawaban yang dapat dijelaskan sebagai berikut :

a. Pemberdayaan Masyarakat Melalui Peningkatan Pengelolaan Badan Usaha Milik Desa (BUMDes) di Desa Cibinuang Kecamatan Kuningan Kabupaten Kuningan; Dalam pemberdayaan tentang pengelolaan Badan Usaha Milik Desa (BUMDes), pengelola sudah berusaha untuk membuat kegiatan yang berkaitan dengan peran masyarakat dalam peningkatan usaha, agar dana yang disalurkan melalui BUMDes, bisa termanfaatkan dengan baik sehingga bisa dipertanggungjawabkan secara normatif, berdasarkan juknis peruntukannya.

b. Meningkatnya lembaga keuangan mikro desa dapat membantu masyarakat dalam pencapaian usahanya; Lembaga keuangan mikro yang ada di Desa Cibinuang lebih diperankan oleh individu, karena belum tampilnya lembaga mikro yang sesuai harapan masyarakat, oleh karena itu kedepan perlu adanya penguatan terhadap pelaksanaan (LKM), sehingga dengan berjalannya lembaga mikro tersebut 
masyarakat akan terbantu dalam hal penggunaan fasilitas yang lebih mudah dan terjangkau.

c. Terjadi singkronisasi program dari pemerintah pusat sampai ke desa tentang kebijakan transformasi LKM yang belum berbadan hukum menjadi BUMDes, koperasi, BPR;

d. Memberikan pembinaan dan pendampingan dalam proses berjalannya BUMDes lebih professional dan akuntabel;

Untuk peningkatan kemampuan dalam pengelolaan BUMDes dengan baik, perlu adanya pendampingan, baik dari pemerintah daerah maupun dari pihak perguruan tinggi yang memahami model pengelolaan BUMDes agar terjadi sinergi antara Pemerintah, Birokrat dan Akademis, sehingga harapan masyarakat bisa tercapai dengan baik.

e. Membantu pemerintah desa, agar berjalan dengan baik Badan Usaha Milik Desa (BUMDes);

f. Membantu pemerintah desa, agar terbentuk unit-unit usaha kecil dan menengah yang dapat meningkatkan ekonomi masyarakat.

Ekonomi masyarakat di Desa Cibinuang, memiliki prosfek baik untuk ditingkatkan, hal ini dibuktikan berjalannya kegiatan sektor usaha, oleh masyarakat dan terjadinya kesempatan kerja bagi penduduk lokal.
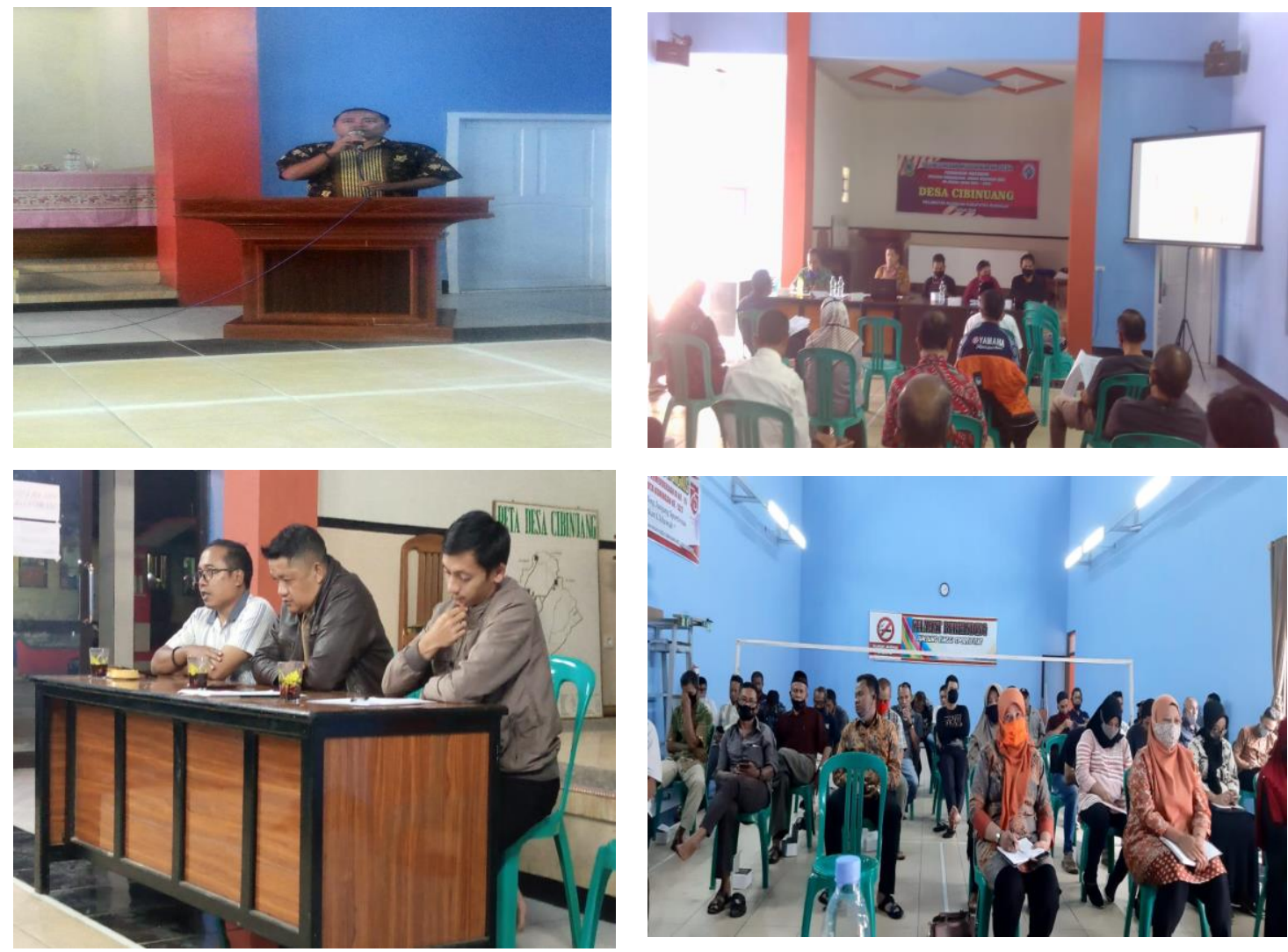

Gambar 1 Rangkaian Kegiatan Pelatihan Pengelolaan BUMDes 
Pelatihan dilaksanakan dalam tiga jenis kegiatan, sesuai dengan metode yang direncanakan sebelumnya. Kegiatan pertama yaitu ceramah dan tanya jawab tentang pengelolaan BUMDes. Kegiatan ini berupaya memberikan pemahaman dan pengetahuan, dan gambaran mengenai pengelolaan BUMDes dan bagaimana mengupayakan agar potensi desa bisa digali untuk mencipatakan peluang usaha bagi masyarakat. Kegiatan ini sekaligus mendorong semangat para pelaku usaha untuk tidak pantang menyerah dan selalu kreatif menemukan ide baru. Sharing informasi dengan tim pengabdi memberikan efek yang positif karena permasalahan-permasalahan terkait kegiatan pengelolaan BUMDes yang muncul dapat dicari solusinya, terutama yang berkaitan dengan pengalokasian dana pendamping dan pemasaran produk local melalui BUMDes. Kegiatan pelatihan ini mengakomodasi ide-ide yang unik dan kreatif dari masing-masing pihak. Setiap peserta dalam kelompok juga memberikan masukan dan pertimbangan dari beberapa ide yang dirumuskan. Dengan demikian setiap anggota punya keleluasaan untuk berpikir kreatif dan menyampaikan pandangannya. Tim pengabdi membantu mengarahkan dan sharing dalam pengelolaan BUMDes MASAGI Desa Cibinuang.

Ada beberapa faktor pendukung pada saat berlangsungnya kegiatan pelatihan ini yaitu:

a. Para peserta memiliki kemauan yang kuat untuk menambah pengetahuan dan pemahaman mengenai manajemen pengelolaan BUMDes. Hal ini dapat dilihat dari antusiasnya para peserta dalam mengikuti kegiatan ini dan banyaknya pertanyaanpertanyaan dalam sesi tanya-jawab dan diskusi yang diajukan peserta sampai berakhirnya acara.

b. Para peserta memiliki minat dan keinginan yang besar untuk memperoleh informasi dan mendapatkan pengetahuan tentang dasar-dasar pengelolaan BUMDes.

c. Kegiatan pelatihan ini disambut baik oleh aparat setempat yang secara langsung ataupun tidak langsung meminta agar bentuk kegiatan seperti ini diadakan berkesinambungan/berkelanjutan sehingga dapat langsung dirasakan manfaatnya bagi para peserta.

Selain factor pendukung dalam kegiatan tersebut, ada beberapa kendala yang dihadapi pada saat pelatihan berlangsung seperti:

a. Para peserta tidak hadir tepat waktu yang telah ditetapkan sehingga acara mundur sekitar 30 menit.

b. Adanya keterbatasan dalam fasilitas pendukung untuk melakukan penyuluhan diantaranya: kurang besarnya layar sebagai media visual dari materi yang disampaikan.

\section{SIMPULAN}

Dari berbagai uraian di atas maka disimpulkan beberapa hal berikut ini:

a. Melalui Pelatihan Peningkatan Pengelolaan Badan Usaha Milik Desa (BUMDes) di Desa Cibinuang Kecamatan Kuningan Kabupaten Kuningan, peningkatan pengelolaan BUMDes memerlukan Sumber Daya Manusia (SDM) yang benar-benar memahami seluk beluk pengelolaan serta mampu memasarkan hasil produk yang dikelola melalui BUMDes. 
b. Perangkat Desa, penglola BUMDes dan pelaku usah local sebagai sasaran program ini terbantukan dan merasa bangga dengan kegiatan dalam meningkatkan Pengelolaan Badan Usaha Milik Desa (BUMDes) dan bisa membuat laporan pertanggungjawaban keuangan dengan baik dan benar, sesuai kaida-kaida keuangan berlaku secara umum.

c. Kegiatan Pelatihan Pengelolaan BUMDes telah mampu memperbaiki proses penatausahaan program BUMDes, baik pengelolaan administrasi, pertanggungjawaban keuangan serta penyaluran bantuan kepada usaha kecil dan menengah, sebagai suatu proses yang dilakukan untuk mengidentifkasi data, menjadi sebuah data yang relevan, yang kemudian dianalisis dan diubah menjadi sebuah informasi yang dapat digunakan untuk pengambilan keputusan.

d. Pengabdian pada masyarakat merupakan salah satu sarana untuk menjembatani dunia pendidikan dengan masyarakat. Di mana Perguruan Tinggi dihadapkan pada masalah bagaimana agar warga masyarakat mampu menghadapi tantangan lebih jauh ke depan di era globalisasi.

e. Kegiatan pengabdian pada masyarakat dengan memberikan penyuluhan kewirausahaan menjadi jembatan bagi Perguruan Tinggi khususnya Universitas Kuningan dengan masyarakat dalam mentransfer wawasan ilmu dan teknologi sehingga dapat langsung dirasakan manfaatnya oleh masyarakat di Kabupaten Kuningan.

\section{SARAN}

Diharapkan pelatihan seperti ini tetap dilaksanakan secara rutin. Dikarenakan perkembangan teknologi yang terus berkembang dan sebagai evaluasi capaian dari tahunketahun. Perlu diadakan kembali pelatihan pemanfaatan teknologi yang lebih luas, bukan hanya untuk meningkatkan jangkauan pemasaran, tetapi untuk pengelolaan dan distribusi yang efektif dan efisien sehingga dimasa yang akan datang penngelolaan BUMDes harus berbasis Teknologi Informasi dan Manajemen Modern.

\section{UCAPAN TERIMA KASIH}

Penulis ucapkan terima kasih kepada Pemerintahan Desa Cibinuang dan Pengelola BUMDes MASAGI Desa Cibinuang Kecamatan Kuningan Kabupaten Kuningan, Dekan FKOM UNIKU, Rektor Universitas Kuningan, Pemerintah Daerah Kabupaten Kuningan atas segala dukungan yang telah diberikan sehingga terselenggaranya kegiatan pengabdian ini.

\section{DAFTAR PUSTAKA}

H.A.W. Widjaja. 2010. Otonomi Desa: Merupakan Otonomi Yang Asli, Bulat dan Utuh. Jakarta: RajaGrafindo.

Juliantara, Dadang. 2003. Pembaruan Desa, Bertumpu Pada Yang Terbawah. Jogjakarta: Lappera.

Kartohadikoesoemo, Soetardjo. 2004. Desa. Jakarta: PN Balai Pustaka.

Roni Nursyamsu. Pelatihan Peningkatan Kapasitas Pemuda Dan Pembuatan Program Kerja Pada Organisasi Pemuda Desa Cibinuang, Kabupaten Kuningan. 
Empowerment : Jurnal Pengabdian Masyarakat, e-ISSN 2598-2052

Vol. 03 Nomor 02.2020. 135-142.

Empowerment : Jurnal Pengabdian Masyarakat, e-ISSN 2598-2052. Vol. 01 Nomor 01. 2018.37-44

Suwari Akhmaddhian. Pelatihan Pembuatan Peraturan Desa Di Kecamatan Banjaran,

Majalengka. Empowerment : Jurnal Pengabdian Masyarakat, e-ISSN 2598-

2052. Vol.03. Nomor 01.2020.6-13

\section{Peraturan Perundang-undangan}

Undang-Undang Nomor 6 Tahun 2014 tentang Desa

Undang-Undang Nomor 23 Tahun 2014 tentang Pemerintahan Daerah.

Peraturan Pemerintah Nomor 72 Tahun 2005 Tentang Desa.

Peraturan Menteri Dalam Negeri Nomor 39 Tahun 2010 Tentang Badan Usaha Milik Desa. 